\title{
Impact of isolated high home systolic blood pressure on diabetic nephropathy in patients with type 2 diabetes mellitus: A 5-year prospective cohort study
}

\author{
Nobuko Kitagawa \\ Kyoto Furitsu Ika Daigaku \\ NORIYUKI KITAGAWA \\ Hidetaka Ushigome \\ Kyoto Furitsu Ika Daigaku \\ Isao Yokota \\ Hokkaido Daigaku \\ Masahide Hamaguchi \\ Kyoto Furitsu Ika Daigaku \\ Mai Asano \\ Kyoto Furitsu Ika Daigaku \\ Masahiro Yamazaki \\ Kyoto Furitsu Ika Daigaku \\ Michiaki Fukui \\ Kyoto Furitsu Ika Daigaku
}

Kyoto Furitsu Ika Daigaku https://orcid.org/0000-0003-3263-9469

Emi Ushigome ( $\nabla$ emis@koto.kpu-m.ac.jp )

Kyoto Prefectural University of Medicine https://orcid.org/0000-0003-1031-4380

Original investigation

Keywords: albuminuria, diabetes mellitus, isolated high home systolic blood pressure, diabetic nephropathy

Posted Date: September 14th, 2020

DOI: https://doi.org/10.21203/rs.3.rs-66901/v1

License: (9) This work is licensed under a Creative Commons Attribution 4.0 International License. Read Full License 


\section{Abstract \\ Background}

A previous 2-year cohort study has shown that isolated high home systolic blood pressure (IH-HSBP) may increase the risk of diabetic nephropathy. However, this association has not been previously assessed over medium to long term.

\section{Methods}

This prospective 5-year cohort study of 424 patients with normoalbuminuria investigated the effect of IHHSBP on the risk of diabetic nephropathy in patients with type 2 diabetes mellitus. Diabetic nephropathy was defined as advancement from normoalbuminuira to micro- or macroalbuminuria.

\section{Results}

Among 424 patients, 75 developed diabetic nephropathy during the study period. Adjusted odds ratio of developing diabetic nephropathy because of IH-HSBP was 2.39 (95\% confidence interval 1.15-4.96, $p=$ 0.02). Sex; body mass index; duration of diabetes mellitus; and levels of hemoglobin A1c, total cholesterol, creatinine; and use of renin-angiotensin-aldosterone system inhibitors were included in the model as covariates.

\section{Conclusions}

IH-HSBP was associated with an increased risk of diabetic nephropathy among type 2 diabetes mellitus patients with normoalbuminuria over medium to long term. These findings suggest that IH-HSBP might be a useful marker in disease prognostication.

\section{Background}

Home blood pressure (HBP) control is paramount to diabetic nephropathy prevention [1]. Several important factors of HBP, including day-to-day variability [2] or pulse pressure [3], have been reported as relevant to the risk of diabetic nephropathy.

Isolated systolic hypertension (ISH) is diagnosed when systolic blood pressure (SBP) is disproportionately high compared to diastolic blood pressure (DBP) [4]. ISH has been shown to increase the risk of premature mortality in patients with cardiovascular disease $[5,6]$; it is a common form of hypertension [7]. 
ISH expressed as HBP (home ISH) has also been shown to affect the risk of diabetic nephropathy. In fact, our group has previously shown that isolated high home systolic blood pressure (IH-HSBP) might be a useful marker in prognostication of diabetic nephropathy, based on data from a 2 year-cohort study [8]. Nevertheless, the follow-up period in that study was relatively short, likely limiting its statistical power. To address this limitation, we performed a follow-up study with patients diagnosed with type 2 diabetes mellitus (DM), aiming to provide valid assessment of the impact of ISH on the risk of diabetic nephropathy in this patient group over medium to long term.

\section{Methods}

We used the same resources in our previous study, which is based on data from the HBP cohort of patients with type 2 diabetes mellitus who had regularly attended the diabetes outpatient clinic at the Kyoto Prefectural University of Medicine Hospital or other general hospitals located in Japan (KAMOGAWA-HBP study) [9].

The present study included patients with type 2 DM; the impact of HBP on the risk of diabetic nephropathy was evaluated. Nephropathy was graded as follows: normoalbuminuria, defined as urinary albumin/creatinine ratio (UACR) $<30 \mathrm{mg}$ per gram of creatinine $(\mathrm{mg} / \mathrm{g} \mathrm{Cr}$ ); microalbuminuria, defined as UACR $30-300 \mathrm{mg} / \mathrm{g}$ Cr; or macroalbuminuria, defined as UACR $>300 \mathrm{mg} / \mathrm{g} \mathrm{Cr}$ [10-14]. Development of diabetic nephropathy was defined as advancement from normoalbuminuira to micro- or macroalbuminuria within 5 years. The study protocol was approved by the local Research Ethics Committee; RBMR-E-349, the study adhered to the principles of the Declaration of Helsinki; informed consent was obtained from all patients prior to enrollment.

\section{Data collection}

Blood samples for biochemical measurements were taken in the morning. Serum lipid profile (including levels of triglycerides, low-density lipoprotein cholesterol, and high-density lipoprotein cholesterol), and levels of creatinine and hemoglobin $\mathrm{A} 1_{\mathrm{C}}(\mathrm{HbA1c})$, and of other biochemical markers were assessed by standard laboratory methods. An immunoturbidimetric assay was used to measure UACR; the mean value of three consecutive urinary measurements was equivalent to UACR. Levels of HbA1c were classified and reported according to the National Glycohemoglobin Standardization Program guidelines, as recommended by the Japan Diabetes Society [15]. Data on patient demographic and clinical characteristics, including sex, age, duration of DM, smoking status, and those on alcohol consumption and antihypertensive medication use were collected at the same time as HBP measurements began. To measure the brachial-ankle pulse wave velocity (baPWV), the volume plethysmographic method was used, which was also the method utilized in our previous cohort study [16]. Diagnosis of diabetic nephropathy was based on the Diagnostic Nephropathy Study Group criteria [17]. Alcohol drinking status (never, social, or everyday) and smoking status (never, past, or current) were checked by interview. Type 2 DM was diagnosed based on the American Diabetes Association criteria [18]. 


\section{HBP measurements}

Patients were instructed to measure their BP three times each morning and evening for 14 consecutive days, and the 14-day average of the three morning and three evening mean values were calculated for each. Patients were instructed to measure their morning BP within 1 hour of waking up, before breakfast, before taking medication, having sat and rested for at least 5 minutes [19]. Similar instructions applied to evening BP measurements, which were obtained before bedtime. Moreover, patients were instructed that the cuff of the measuring device should be placed around the contralateral side of the dominant arm, with its position maintained at the level of the heart. HBP measurements were performed with an automated device, HEM-70801C (Omron Healthcare Co. Ltd, Kyoto, Japan), which uses a digital display to present values of SBP/DBP and heart rate, measured using the cuff-oscillometric method. HEM70801C uses the same components and BP-determining algorithm as those of another device, HEM705IT, which was previously validated and satisfied the criteria of the British Hypertension Society protocol [20].

Patients were classified into four groups based on HBP levels: normal HBP (morning SBP $<125 \mathrm{mmHg}$ and morning DBP $<75 \mathrm{mmHg}$ ), IH-HSBP (morning SBP $\geq 125 \mathrm{mmHg}$ and morning DBP $<75 \mathrm{mmHg}$, isolated high home DBP (IH-HDBP) (morning SBP $<125 \mathrm{mmHg}$ and morning DBP $\geq 75 \mathrm{mmHg}$ ), and high HBP (morning SBP $\geq 125 \mathrm{mmHg}$ and morning $\mathrm{DBP} \geq 75 \mathrm{mmHg}$ ) [21].

\section{Statistical analysis}

Participant baseline characteristics were reported as median with interquartile range or count, as suitable. Logistic regression analysis was used to assess the relationship between IH-HSBP, IH-HDBP, and high HBP, and the risk of diabetic nephropathy, with "normal HBP" set as a reference. The following factors were included as covariates in adjusted models: sex, body mass index (BMI), duration of diabetes, levels of $\mathrm{HbA} 1 \mathrm{c}$, of total cholesterol, and of creatinine, and use of antihypertensive medication (Model 2). Separate adjustments were made for use of renin-angiotensin-aldosterone system inhibitors instead of antihypertensive medications (Model 3).

In addition, subgroup analyses were performed for age ( $\geq 65$ years vs. $<65$ years) and SBP control ( $\geq 135 \mathrm{mmHg}$ vs. $<135 \mathrm{mmHg}$ ). $P$-values $<0.05$ were considered indicative of statistically significant findings. Statistical analyses were performed using JMP version 13.2 software (SAS Institute Inc., Cary, NC, USA).

\section{Results}

A total of 1,372 consecutive patients with type 2 DM, aged 20-90 years were recruited for this study. Sixty-four and 422 patients were excluded due to insufficient HBP and UACR data, respectively. In addition, 148 patients who were newly prescribed angiotensin II receptor blocker (ARB) or angiotensinconverting-enzyme inhibitor (ACE-I) or stopped with them during follow-up, 263 patients who were with microalbuminuria or macroalbuminuria were also excluded. 
The final sample included 424 patients with normoalbuminuria (Fig. 1). Among them, during 5-year follow-up period, 74 patients developed microalbuminuria and 1 patient developed macroalbuminuria.

Patient baseline demographic and clinical characteristics are presented in Table 1. Median (interquartile range) age, duration of diabetes, $\mathrm{BMI}$, and levels of total cholesterol and those of $\mathrm{HbA} 1_{\mathrm{C}}$ were 64.0 (59.070.0) years, $9.0(4.8-15.0)$ years, $23.0(21.4-25.3) \mathrm{kg} / \mathrm{m}^{2}, 191(170-212) \mathrm{mg} / \mathrm{dL}$, and $6.6(6.2-7.3) \%$, respectively. The unadjusted odds ratio (OR) with $95 \%$ confidence interval $(\mathrm{Cl})$ of developing diabetic nephropathy given IH-HSBP, IH-HDBP, and high HBP was 2.68 (1.36-5.30), $0.78(0.21-2.81)$, and 1.63 (0.87-3.04), respectively (Table 2$)$, using normal HBP as a reference. In multivariate analyses, adjusted OR $(95 \% \mathrm{Cl})$ of developing diabetic nephropathy given IH-HSBP was $2.36(1.14-4.89, p=0.02)$ (Model 2), and $2.39(1.15-4.96, p=0.02)$ in Model 3 (Table 2). 
Table 1

Characteristics of patients

\section{Male/female}

Age (y)

Duration of diabetes $(y)$

Body mass index $\left(\mathrm{kg} / \mathrm{m}^{2}\right)$

Mean morning systolic blood pressure $(\mathrm{mmHg})$

Mean morning diastolic blood pressure $(\mathrm{mmHg})$

Mean evening systolic blood pressure $(\mathrm{mmHg})$

Mean evening diastolic blood pressure $(\mathrm{mmHg})$

Clinic systolic blood pressure $(\mathrm{mmHg})$

Clinic diastolic blood pressure $(\mathrm{mmHg})$

Hemoglobin A1c (\%)

Hemoglobin A1c $(\mathrm{mmol} / \mathrm{mol})$

Total cholesterol $(\mathrm{mg} / \mathrm{dL})$

Creatinine $(\mathrm{mg} / \mathrm{dL})$

baPWV

Smoking status (never/past/current)

Alcohol drinking (never/social/everyday)

Retinopathy (NDR/SDR/PDR)

Neuropathy $(-/+)$

Macrovascular complication $(-/+)$

Antihypertensive medication (-/+)

RAS (-/+)
$228 / 196$

$64.0(59.0-70.0)$

$9.0(4.8-15.0)$

$23.0(21.4-25.3)$

$128.1(117.4-138.2)$

$73.2(66.5-79.9)$

$123.4(115.0-133.1)$

$67.7(61.9-74.2)$

$136.0(123.0-146.0)$

$76.7(70.0-80.3)$

$6.6(6.2-7.3)$

$52.0(48.6-59.5)$

191 (170-212)

$0.70(0.58-0.83)$

1762(1501-2002)

$258 / 125 / 65$

$263 / 92 / 96$

$353 / 61 / 33$

$360 / 110$

$385 / 86$

232/192

$267 / 156$

For categorical variables, $\mathrm{n}(\%)$ is presented. For continuous variables, median (interquartile range) is presented. baPWV, brachial ankle pulse wave velocity; NDR, no diabetic retinopathy; SDR, simple diabetic retinopathy; PDR, proliferative diabetic retinopathy; RAS, renin-angiotensin-aldosterone system. 
Table 2

Unadjusted and adjusted odds ratios for the development of diabetic nephropathy.

\begin{tabular}{|c|c|c|c|c|c|c|}
\hline \multirow{2}{*}{$\begin{array}{l}\text { Hypertension status } \\
\text { (n) }\end{array}$} & \multicolumn{2}{|l|}{ Model 1} & \multicolumn{2}{|l|}{ * Model 2} & \multicolumn{2}{|l|}{ * Model 3} \\
\hline & $\begin{array}{l}\text { Unadjusted OR } \\
(95 \% \mathrm{Cl})\end{array}$ & $\begin{array}{l}P \\
\text { Value }\end{array}$ & $\begin{array}{l}\text { Adjusted OR } \\
(95 \% \mathrm{Cl})\end{array}$ & $\begin{array}{l}P \\
\text { Value }\end{array}$ & $\begin{array}{l}\text { Adjusted OR } \\
(95 \% \mathrm{Cl})\end{array}$ & $\begin{array}{l}P \\
\text { Value }\end{array}$ \\
\hline $\begin{array}{l}\text { Normal HBP group } \\
(166)\end{array}$ & 1 & & 1 & & 1 & \\
\hline $\begin{array}{l}\text { Isolated high HSBP } \\
\text { group (106) }\end{array}$ & $\begin{array}{l}2.68(1.36- \\
5.30)\end{array}$ & 0.004 & $\begin{array}{l}2.36(1.14- \\
4.89)\end{array}$ & 0.020 & $\begin{array}{l}2.39(1.15- \\
4.96)\end{array}$ & 0.019 \\
\hline $\begin{array}{l}\text { Isolated high HDBP } \\
\text { group (35) }\end{array}$ & $\begin{array}{l}0.78(0.21- \\
2.81)\end{array}$ & 0.701 & $\begin{array}{l}0.54(0.12- \\
2.53)\end{array}$ & 0.438 & $\begin{array}{l}0.54(0.12- \\
52.52)\end{array}$ & 0.434 \\
\hline $\begin{array}{l}\text { High HBP group } \\
(170)\end{array}$ & $\begin{array}{l}1.63(0.87- \\
3.04)\end{array}$ & 0.126 & $\begin{array}{l}1.57(0.79- \\
3.12)\end{array}$ & 0.193 & $\begin{array}{l}1.60(0.81- \\
3.17)\end{array}$ & 0.173 \\
\hline \multicolumn{7}{|c|}{ HBP, home blood pressure; HSBP, home systolic blood pressure; } \\
\hline \multicolumn{7}{|c|}{$\begin{array}{l}\text { * Model 2: Odds ratios were adjusted for sex, age, duration of diabetes mellitus, body mass index, } \\
\text { hemoglobin } A_{1 C} \text {, total cholesterol, creatinine and use of antihypertensive medications. }\end{array}$} \\
\hline
\end{tabular}

In sub-group analyses, an adjusted OR $(95 \% \mathrm{Cl})$ for developing nephropathy given IH-HSBP was 1.68 (0.66-4.27) among age $\geq 65$ years (Table 3 ); meanwhile, in age $<65$ years an adjusted $\mathrm{OR}(95 \% \mathrm{Cl})$ was 3.06 (0.63-15.0) (Table 3) using normal HBP as a reference. 
Table 3

Unadjusted and adjusted odds ratios for the development of diabetic nephropathy in patients equal to or more than 65 years old and less than 65 years old.

\begin{tabular}{|c|c|c|c|c|c|c|}
\hline \multirow{2}{*}{$\begin{array}{l}\text { Hypertension } \\
\text { status }\end{array}$} & \multicolumn{2}{|l|}{ Model 1} & \multicolumn{2}{|l|}{ * Model 2} & \multicolumn{2}{|l|}{ * Model 3} \\
\hline & $\begin{array}{l}\text { Unadjusted OR } \\
(95 \% \mathrm{Cl})\end{array}$ & $\begin{array}{l}P \\
\text { Value }\end{array}$ & $\begin{array}{l}\text { Adjusted OR } \\
(95 \% \mathrm{Cl})\end{array}$ & $\begin{array}{l}P \\
\text { Value }\end{array}$ & $\begin{array}{l}\text { Adjusted OR } \\
\text { (95\%Cl) }\end{array}$ & $\begin{array}{l}P \\
\text { Value }\end{array}$ \\
\hline \multicolumn{7}{|l|}{$\geq 65$ years old } \\
\hline $\begin{array}{l}\text { Normal HBP } \\
\text { group }\end{array}$ & 1 & & 1 & & 1 & \\
\hline $\begin{array}{l}\text { Isolated high } \\
\text { HSBP group }\end{array}$ & $\begin{array}{l}1.90(0.85- \\
4.23)\end{array}$ & 0.116 & $\begin{array}{l}1.70(0.67- \\
4.33)\end{array}$ & 0.263 & $\begin{array}{l}1.68(0.66- \\
4.27)\end{array}$ & 0.275 \\
\hline \multicolumn{7}{|l|}{$\otimes 65$ years old } \\
\hline $\begin{array}{l}\text { Normal HBP } \\
\text { group }\end{array}$ & 1 & & 1 & & 1 & \\
\hline $\begin{array}{l}\text { Isolated high } \\
\text { HSBP group }\end{array}$ & $\begin{array}{l}3.08(0.76- \\
12.5)\end{array}$ & 0.116 & $\begin{array}{l}3.07(0.62- \\
15.1)\end{array}$ & 0.167 & $\begin{array}{l}3.06(0.63- \\
15.0)\end{array}$ & 0.167 \\
\hline \multicolumn{7}{|c|}{ HBP, home blood pressure; HSBP, home systolic blood pressure; } \\
\hline \multicolumn{7}{|c|}{$\begin{array}{l}\text { * Model 2: Odds ratios were adjusted for sex, age, duration of diabetes mellitus, body mass index, } \\
\text { hemoglobin } A_{1 C} \text {, total cholesterol, creatinine and use of antihypertensive medications. }\end{array}$} \\
\hline $\begin{array}{l}\text { * Model 3: Od } \\
\text { renin angioten }\end{array}$ & $\begin{array}{l}\text { were adjusted } \\
\text { em inhibitors in }\end{array}$ & $\begin{array}{l}\text { ariabl } \\
\mathrm{d} \text { of } \mathrm{u}\end{array}$ & $\begin{array}{l}\text { in model } 2 \text { an } \\
\text { of antihyperte }\end{array}$ & $\begin{array}{l}\text { ditiona } \\
\text { e medi }\end{array}$ & $\begin{array}{l}\text { djustment fol } \\
\text { tions. }\end{array}$ & \\
\hline
\end{tabular}

In subgroup analysis of SBP control, in patients with equal to or more than $135 \mathrm{mmHg}$, the adjusted odds ratio $(95 \% \mathrm{Cl})$ of IH-HSBP, using normal HBP as a reference group for the development of diabetic nephropathy, was 5.39 (1.92-18.6) (Table 4). In patients with $<135 \mathrm{mmHg}$, the adjusted odds ratio (95\% $\mathrm{Cl})$ of IH-HSBP was $0.71(0.32-1.35)$ (Table 4$)$. 
Table 4

Unadjusted and adjusted odds ratios for the development of diabetic nephropathy in patients according to systolic blood pressure.

\begin{tabular}{|c|c|c|c|c|c|c|}
\hline \multirow{2}{*}{$\begin{array}{l}\text { Hypertension } \\
\text { status }\end{array}$} & \multicolumn{2}{|l|}{ Model 1} & \multicolumn{2}{|l|}{ * Model 2} & \multicolumn{2}{|l|}{ * Model 3} \\
\hline & $\begin{array}{l}\text { Unadjusted OR } \\
(95 \% \mathrm{Cl})\end{array}$ & $\begin{array}{l}P \\
\text { Value }\end{array}$ & $\begin{array}{l}\text { Adjusted OR } \\
(95 \% \mathrm{Cl})\end{array}$ & $\begin{array}{l}P \\
\text { Value }\end{array}$ & $\begin{array}{l}\text { Adjusted OR } \\
(95 \% \mathrm{Cl})\end{array}$ & $\begin{array}{l}P \\
\text { Value }\end{array}$ \\
\hline \multicolumn{7}{|l|}{$\geq 135 \mathrm{mmHg}$} \\
\hline $\begin{array}{l}\text { Normal HBP } \\
\text { group }\end{array}$ & 1 & & 1 & & 1 & \\
\hline $\begin{array}{l}\text { Isolated high } \\
\text { HSBP group }\end{array}$ & $\begin{array}{l}4.21(1.73- \\
12.6)\end{array}$ & 0.0009 & $\begin{array}{l}5.59(2.02- \\
19.1)\end{array}$ & 0.0005 & $\begin{array}{l}5.39(1.92- \\
18.6)\end{array}$ & 0.0008 \\
\hline \multicolumn{7}{|l|}{ ه $135 \mathrm{mmHg}$} \\
\hline $\begin{array}{l}\text { Normal HBP } \\
\text { group }\end{array}$ & 1 & & 1 & & 1 & \\
\hline $\begin{array}{l}\text { Isolated high } \\
\text { HSBP group }\end{array}$ & $\begin{array}{l}1.31(0.63- \\
2.52)\end{array}$ & 0.452 & $\begin{array}{l}0.75(0.33- \\
1.57)\end{array}$ & 0.449 & $\begin{array}{l}0.71(0.32- \\
1.35)\end{array}$ & 0.384 \\
\hline \multicolumn{7}{|c|}{ HBP, home blood pressure; HSBP, home systolic blood pressure; } \\
\hline \multicolumn{7}{|c|}{$\begin{array}{l}\text { * Model 2: Odds ratios were adjusted for sex, age, duration of diabetes mellitus, body mass index, } \\
\text { hemoglobin } A_{1 C} \text {, total cholesterol, creatinine and use of antihypertensive medications. }\end{array}$} \\
\hline $\begin{array}{l}\text { * Model 3: Od } \\
\text { renin angioten }\end{array}$ & $\begin{array}{l}\text { s were adjusted } \\
\text { tem inhibitors ir }\end{array}$ & $\begin{array}{l}\text { variabl } \\
\text { ad of } u\end{array}$ & $\begin{array}{l}\text { in model } 2 \text { ar } \\
\text { of antihypert }\end{array}$ & $\begin{array}{l}\text { dditional } \\
\text { ve medic }\end{array}$ & $\begin{array}{l}\text { djustment fol } \\
\text { tions. }\end{array}$ & se of \\
\hline
\end{tabular}

\section{Discussion}

In the present study, IH-HSBP was associated with increased risk of diabetic nephropathy in patients with type 2 DM during a 5-year follow-up period.

The results are expected to be in line with the previous 2 year-cohort study [8]. The mechanism likely to account for the association between IH-HSBP and diabetic nephropathy risk has been described elsewhere [22-28]. Increased arterial stiffness has been associated with the development of ISH [29]. Further arterial aging might result in additional increase of IH-HSBP, which is a risk factor for target organ dysfunction [30] and diabetic nephropathy [31].

In the present study, IH-HSBP was associated with an increased risk of diabetic nephropathy; however, high HBP was not. The patients in the IH-HSBP group were older than those in the high HBP group (69.6 vs. 60.6 years, $P<0.001)$. When arterial stiffness was compared between the IH-HSBP and High-HBP groups using the baPWV measurements, there appeared to be higher arterial stiffness among patients in the IH-HSBP group than in those in the High-HBP group (1892 vs. $1784 \mathrm{~m} / \mathrm{s}, \mathrm{P}=0.053$ ) [16, 32]. Arterial aging in IH-HSBP may be associated with increased odds for the development of diabetic nephropathy. 
ISH among young-to-middle-aged Japanese people is associated with premature mortality due to cardiovascular disease [33]. In the present study, age-stratified sub-group analysis revealed that the adjusted OR was higher among patients aged $<65$ years than in those aged $\geq 65$ years. These findings were consistent with those of our previous study [8]. Meanwhile, subgroup analyses stratified by SBP status revealed that IH-HSBP increased the risk of diabetic nephropathy only in patients with SBP $\geq$ $135 \mathrm{mmHg}$. Patients with IH-HSBP may be at a lower risk if their SBP measurements meet the hypertension diagnostic criteria of less than $135 \mathrm{mmHg}$ [34]. It should be noted that patients in this group were older $(66.2$ vs. 61.6 years old, $P<0.001)$ and more likely to take antihypertensive medications $(69.1 \%$ vs $45.5 \%$ ) than patients with SBP $<135 \mathrm{mmHg}$. Patients with SBP $\geq 135 \mathrm{mmHg}$ had remarkable ISH, which would be associated with arterial damage and diabetic nephropathy.

To the best of our knowledge, this is the first study to evaluate the impact of IH-HSBP on the risk of diabetic nephropathy in patients with type $2 \mathrm{DM}$ over a medium to long term.

Nevertheless, this study has several limitations, which should be considered when interpreting its findings. First, we did not have data on salt intake, protein intake, or levels of exercise, which would be associated with the development of diabetic nephropathy [27, 35-37]. In this regard, we could not clearly identify the prognostic significance of HBP for the development of diabetic nephropathy even in a longer study. Second, only Japanese men and women were included in the study population. Therefore, these findings might not be generalized to other ethnic groups. Third, only single baseline measurement of BP were performed. This may be potential bias. However, the association of target organ damage was confirmed by BP at baseline or during follow-up [38]. Single BP assessments would be reliable when the addition of subsequent values do not significantly alter the results.

\section{Conclusions}

In conclusion, $\mathrm{IH}-\mathrm{HSBP}$ in patients with type 2 diabetes mellitus was a prognostic factor for the development of diabetic nephropathy in a prospective 5-year cohort study.

\section{Abbreviations}

IH-HSBP, isolated high home systolic blood pressure

HBP, home blood pressure

$\mathrm{ISH}$, isolated systolic hypertension

SBP, systolic blood pressure

DBP, diastolic blood pressure

DM diabetes mellitus 
UACR, urinary albumin/creatinine ratio

HbA1c, hemoglobin $A 1_{C}$

$\mathrm{BMI}$, body mass index

baPWV, brachial-ankle pulse wave velocity

OR, odds ratio

$\mathrm{Cl}$, confidence interval

\section{Declarations}

\section{Ethics approval and consent to participate}

All study participants provided informed consent, and the study design was approved by the appropriate ethics review board.

\section{Consent for publication}

All authors have read, understood the journal's policies, and consent for publication.

\section{Availability of data and materials}

The datasets used and/or analysed during the current study are available from the corresponding author on reasonable request.

\section{Competing interests}

N. K., N. K., E. U., H. U., I. Y., M. H., M. A., M. Y., and M. F. have received grant and research support from AstraZeneca plc, Astellas Pharma Inc., Bristol-Myers Squibb K.K., Daiichi Sankyo Co., Ltd., Eli Lilly Japan K.K., Kyowa Hakko Kirin Company Ltd., Kowa Pharmaceutical Co., Ltd., Kissei Pharmaceutical Co., Ltd., MSD K.K., Mitsubishi Tanabe Pharma Corp., Novo Nordisk Pharma Ltd., Nippon Chemiphar Company Ltd., Sanwa Kagaku Kenkyusho Co., Ltd., Sanofi K.K., Taisho Toyama Pharmaceutical Co., Ltd., Takeda Pharmaceutical Co., Ltd., and TERUMO Co. For the remaining authors were non-declared. The sponsors were not involved in the study design; in the collection, analysis, interpretation of data; nor in the writing of this manuscript; nor in the decision to submit the article for publication. The authors, their immediate families, and any research foundations with which they are affiliated have not received any financial payments or other benefits from any commercial entity related to the subject of this article. The authors declare that although they are affiliated with a department that is supported financially by 
pharmaceutical company, the authors received no current funding for this study and department affiliation does not alter their adherence to all journal policies on sharing data and materials.

\section{Funding}

E. U. received grant support from the Japanese Study Group for Physiology and Management of Blood Pressure and the Astellas Foundation for Research on Metabolic Disorders (grant number: 4024).

\section{Authors' contribution}

N. K. and N. K. designed the study, performed data analyses and reviewed/edited the manuscript. E.U. designed the study, contributed to the collection of research data, performed data analyses, drafted the manuscript, and was the main study physician responsible for the KAMOGAWA-HBP study in Kyoto Prefectural University of Medicine, Graduate School of Medical Science. M. H., M. A. and M.Y. designed the study protocol, reviewed data reports, and reviewed the study manuscript. H.U. designed the study protocol, reviewed data reports, contributed to discussion, and reviewed the study manuscript. I.Y. supervised data analysis, contributed to manuscript preparation, contributed to discussion, and reviewed/edited the manuscript. M.F. designed the protocol, performed data analyses, drafted the manuscript, and was the principal investigator of the Kyoto Prefectural University of Medicine, Graduate School of Medical Science and lead principal investigator for the study. All authors reviewed and provided edits and comments on manuscript drafts. N.K. is the guarantor of this work and, as such, had full access to all the data in the study and takes responsibility for the integrity of the data and the accuracy of the data analysis.

\section{Acknowledgments}

We thank Naoko Higo R.N., Machiko Hasegawa R.N., and Terumi Kaneko R.N. of the Kyoto Prefectural University of Medicine, for teaching patients how to measure their blood pressure and Sayoko Horibe, Hiroko Kawamura and Aiko Aida also of the Kyoto Prefectural University of Medicine, for their secretarial assistance. We thank Editage for English language editing

\section{References}

1. Ushigome E, Oyabu C, Tanaka T, Hasegawa G, Ohnishi M, Tsunoda S, et al. Impact of masked hypertension on diabetic nephropathy in patients with type II diabetes: a KAMOGAWA-HBP study. J Am Soc Hypertens. 2018;12:364-71.

2. Ushigome E, Matsumoto S, Oyabu C, Kitagawa N, Tanaka T, Hasegawa G, et al. Prognostic significance of day-by-day variability of home blood pressure on progression to macroalbuminuria in patients with diabetes. J Hypertens. 2018;36:1068-75. 
3. Kitagawa N, Ushigome E, Matsumoto S, Oyabu C, Ushigome H, Yokota I, et al. Prognostic significance of home pulse pressure for progression of diabetic nephropathy: KAMOGAWA-HBP Study. Hypertens Res. 2018;41:363-71.

4. Fletcher AE, Bulpitt CJ. Isolated systolic hypertension in the elderly. Cardiovasc Risk Factors. 1992;2:133-9.

5. Lakatta EG. Mechanism of hypertension in the elderly. J Am Geriatr Soc. 1989;7:780-90.

6. Messerli FH, Ventura H, Aristimuno GG, Suarez DH, Dreslinski GR, Frohlich ED. Arterial compliance in systolic hypertension. Clin Exp Hypertens A. 1982;4:1037-44.

7. Byyny RL. Hypertension in the elderly. In: Laragh JH, Brenner BM, editors. Hypertension. Pathophysiology, diagnosis, and management. New York: Raven Press; 1995. 227 - 51.

8. Kitagawa N, Ushigome E, Tanaka T, Hasegawa G, Nakamura N, Ohnishi M, et al. Isolated high home systolic blood pressure in patients with type 2 diabetes is a prognostic factor for the development of diabetic nephropathy: KAMOGAWA-HBP Study. Diabetes Res Clin Pract. 2019;158:107920.

9. Ushigome E, Oyabu C, Tanaka T, Hasegawa G, Ohnishi M, Tsunoda S, et al. Impact of masked hypertension on diabetic nephropathy in patients with type II diabetes: a KAMOGAWA-HBP study. J Am Soc Hypertens. 2018;12:364-71.

10. Gerstein HC, Mann J, Yi Q, Zinman B, Dinneen SF, Hoogwerf B, et al. Albuminuria and risk of cardiovascular events, death, and heart failure in diabetic and nondiabetic individuals. JAMA. 2001;286:421-6.

11. Kramer H, Jacobs DR, Bild D, Post W, Saad MF, Detrano R, et al. Urine albumin excretion and subclinical cardiovascular disease: The multi-ethnic study of atherosclerosis. Hypertension. 2005;46:38-43.

12. Krolewski AS, Niewczas MA, Skupien J, Gohda T, Smiles A, Eckfeldt JH, et al. Early progressive renal decline precedes the onset of microalbuminuria and its progression to macroalbuminuria. Diabetes Care. 2014;37:226-34.

13. Ushigome E, Fukui M, Sakabe K, Tanaka M, Inada S, Omoto A, et al. Uncontrolled home blood pressure in the morning is associated with nephropathy in Japanese type 2 diabetes. Heart Vessels. 2011;26:609-15.

14. Nakade Y, Toyama T, Furuichi K, et al. Impact of kidney function and urinary protein excretion on intima-media thickness in Japanese patients with type 2 diabetes. Clin Exp Nephrol. 2015;19:90917.

15. Kashiwagi A, Kasuga M, Araki E, Oka Y, Hanafusa T, Ito H, et al. International clinical harmonization of glycated hemoglobin in Japan: From Japan Diabetes Society to National Glycohemoglobin Standardization Program values. J Diabetes Investig. 2012;3:39-40.

16. Kitagawa N, Ushigome E, Matsumoto S, Oyabu C, Ushigome H, Yokota I, et al. Threshold value of home pulse pressure predicting arterial stiffness in patients with type 2 diabetes: KAMOGAWA-HBP study. J Clin Hypertens. 2018;20:472-7. 
17. Yasuda H, Sanada M, Kitada K, Kitajima S, Miyajima Y, Fukamachi M, et al. Rationale and usefulness of newly devised abbreviated diagnostic criteria and staging for diabetic polyneuropathy. Diabetes Res Clin Pract. 2007;77:178-83.

18. Expert Committee on the Diagnosis and Classification of Diabetes Mellitus. Report of the Expert Committee on the Diagnosis and Classification of Diabetes Mellitus. Diabetes Care. 2002;25:5-20.

19. Imai Y, Otsuka K, Kawano Y, Shimada K, Hayashi H, Tochikubo O, et al. Japanese Society of Hypertension (JSH) guidelines for self-monitoring of blood pressure at home. Hypertens Res. 2003;26:771-82.

20. Coleman A, Fraaman P, Steel S, Shennan A. Validation of the Omron 705IT (HEM-759-E) oscillometric blood pressure monitoring device according to the British Hypertension Society protocol. Blood Press Monit. 2006;11:27-32.

21. Kai H. Blood pressure management in patients with type 2 diabetes mellitus. Hypertens Res. 2017;40:721-9.

22. Franklin SS, Gustin W 4th, Wong ND, Larson MG, Weber MA, Kannel WB, et al. Hemodynamic patterns of age-related changes in blood pressure. Framingham Heart Study Circulation. 1997;96:308-15.

23. Safar ME. Arterial aging-hemodynamic changes and therapeutic options. Nat Rev Cardiol. 2010;7:442-9.

24. Mitchell GF, Conlin PR, Dunlap ME, Lacourcière Y, Arnold JM, Ogilvie RI, et al. Aortic diameter, wall stiffness, and wave reflection in systolic hypertension Hypertension. 2008;51:105-11.

25. Messerli FH, Frohlich ED, Suarez DH, Reisin E, Dreslinski GR, et al. Borderline hypertension: relationship between age, hemodynamics, and circulating catecholamines. Circulation. 1981;64:760-4.

26. Julius S, Pascual AV, London R. Role of parasympathetic inhibition in the hyperkinetic type borderline hypertension. Circulation. 1971;44:413-8.

27. Ekundayo OJ, Allman RM, Sanders PW, Aban I, Love TE, Arnett D, et al. Isolated systolic hypertension and incident heart failure in older adults: A propensity-matched study. Hypertension. 2009;53:45865.

28. DSell DR, Monnier VM. Molecular basis of arterial stiffening: role of glycation - a mini-review. Gerontology. 2012;58:227-37.

29. Kamoi K, Miyakoshi M, Soda S, Kaneko S, Nakagawa O. Usefulness of home blood pressure measurement in the morning in type 2 diabetic patients. Diabetes Care. 2002;25:2218-23.

30. Tomiyama H, Shiina K, Nakano H, Iwasaki Y, Matsumoto C, Fujii M, et al. Arterial stiffness and pressure wave reflection in the development of isolated diastolic hypertension. J Hypertens. 2020. doi:10.1097/HJH.0000000000002519.

31. Ushigome E, Hamaguchi M, Matsumoto S, Oyabu C, Omoto A, Tanaka T, et al. Optimal home SBP targets for preventing the progression of diabetic nephropathy in patients with type 2 diabetes mellitus. J Hypertens. 2015;33:1853-9. discussion 1859. 
32. Ninomiya T, Kojima I, Doi Y, Fukuhara M, Hirakawa Y, Hata J, et al. Brachial-ankle pulse wave velocity predicts the development of cardiovascular disease in a general Japanese population: the Hisayama study. J Hypertens. 2013;31:477-83.

33. Hiramatsu T, Miura K, Ohkubo T, Kadoya A, Kondo K, Kita Y, et al. Isolated systolic hypertension and 29-year cardiovascular mortality risk in Japanese adults aged 30-49 years. J Hypertens. 2020. doi:10.1097/HJH.0000000000002533.

34. Umemura S, Arima H, Arima S, Asayama K, Dohi Y, Hirooka Y, et al. The Japanese Society of Hypertension Guidelines for the Management of Hypertension (JSH 2019). Hypertens Res. 2019;42:1235-481.

35. Ha SK. Dietary salt intake and hypertension Electrolyte. Blood Press. 2014;12:7-18.

36. Machnik A, Neuhofer W, Jantsch J, Dahlmann A, Tammela T, Machura K, et al. Macrophages regulate salt-dependent volume and blood pressure through a vascular endothelial growth factor-C-dependent buffering mechanism. Nat Med. 2009;15:545-52.

37. Zhu HG, Jiang ZS, Gong PY, Zhang DM, Zou ZW, Zhang Q, et al. Efficacy of low-protein diet for diabetic nephropathy: a systematic review of randomized controlled trials. Lipids Health Dis. 2018;17:141.

38. Zhao W, Katzmarzyk PT, Horswell R, Wang Y, Li W, Johnson J, et al. Aggressive blood pressure control increases coronary heart disease risk among diabetic patients. Diabetes Care. 2013;36:328796.

\section{Figures}




\begin{tabular}{|c|}
\hline KAMOGAWA HBP cohort, Registration \\
March 1 $^{\text {st }},{\text { 2008-October } 31^{\text {st }}}, 2015$ \\
$\mathrm{~N}=1372$
\end{tabular}

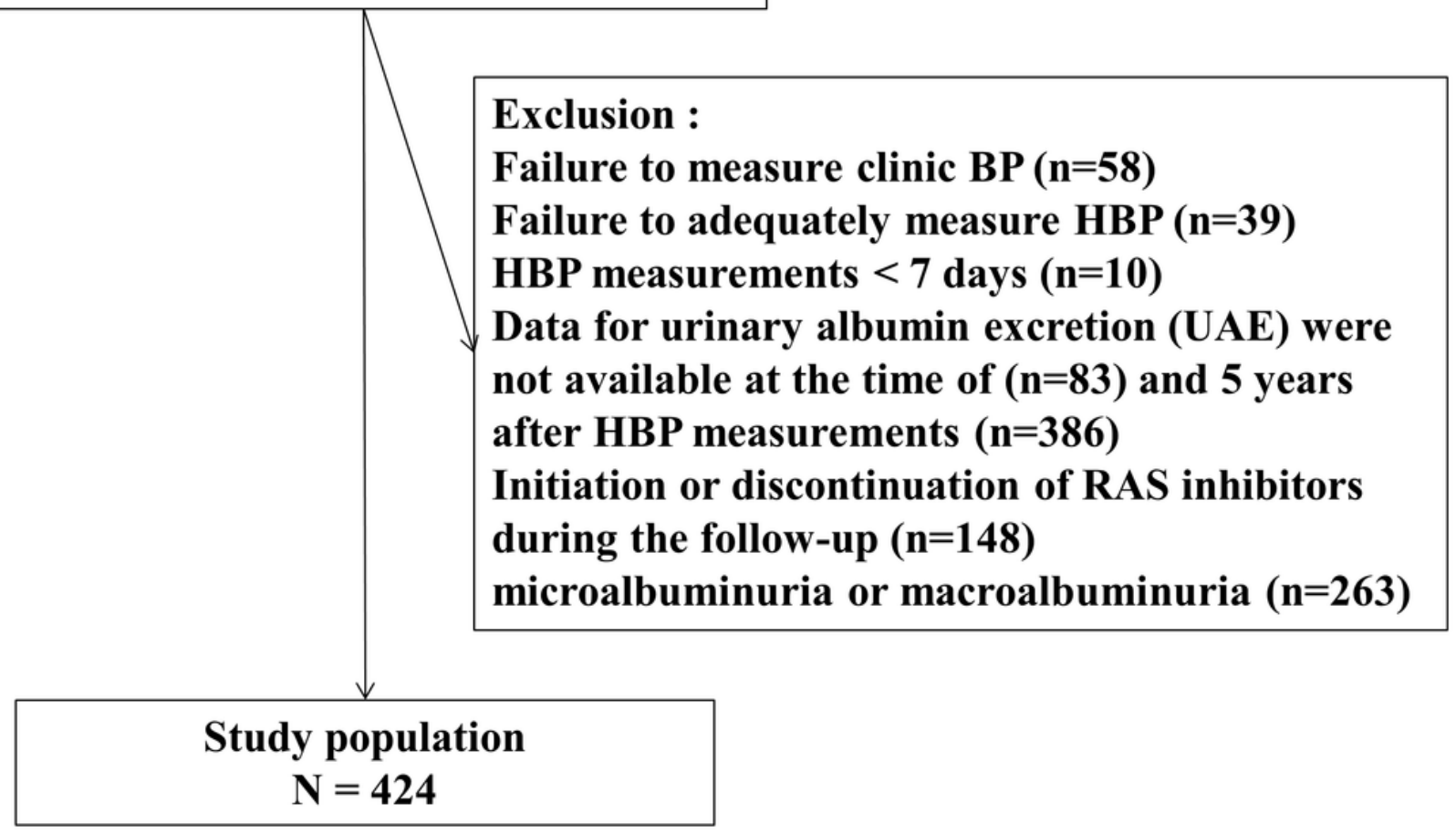

Figure 1

Study flow diagram for the registration of patients. 